\title{
A Brief Account on Metal-Based Drugs in Medicinal Inorganic Chemistry
}

\author{
Santarupa Thakurta* \\ Department of Chemistry, Prabhu Jagatbandhu College, Howrah, India \\ Submission: February 09, 2018; Published: February 23, 2018 \\ *Corresponding author: Santarupa Thakurta, Department of Chemistry, Prabhu Jagatbandhu College, Howrah, India, \\ Email: sthakurtaju@yahoo.co.in
}

\begin{abstract}
The discovery of arsenic-based drug "Salvarsan' to treat syphilis in 1912 can be considered as the first evidence of the use of metals in medicine. Since then medicinal inorganic chemistry, which deals with the application of inorganic chemistry to therapy or diagnosis of disease, has become the most emerging area of research. The complexes of transition metal ions, especially those derived from chelating ligands find potential use as antiviral, anti-inflammatory, antitumor agents. Nowadays, metal elements such as platinum, titanium, antimony, selenium, silver, gold, vanadium, copper, manganese, germanium, iron, ruthenium, gadolinium and technetium have gained attention for their significant roles as pharmaceuticals as well as diagnostic agents [1]. The aim of this mini-review article is to highlight some of the most widely used inorganic compounds as therapeutic metallodrugs and diagnostic agents.
\end{abstract}

Keywords: Metal-based drugs; Salvarsan; metallodrugs; Platinum; Titanium

\section{Discussion}

\section{Therapeutic uses}

The historically proven use of metal-based remedies was introduced by ancient civilizations of Mesopotamia, Egypt, India and China. Minor stomach pain and digestion problems have been treated with metallodrugs for centuries. Oral antacid preparations of sodium(I), magnesium(II), calcium(II), and aluminium (III) as their basic carbonate, hydrogen carbonate or hydroxide salts neutralize excessive acidity in the stomach by increasing the $\mathrm{pH}$ and reducing the secretion of acid by gastric cells. The use of zinc sulphate for would healing purpose and zinc gluconate lozenges for the treatment of common cold in adults are long recognised. We are familiar with the use of silver sulphadiazene, applied as a cream formulation or aqueous solution to prevent infections resulting from serious burns. It is established that Rheumatoid arthritis, a painful inflammatory condition where the cartilage between bone joints is lost over time, can be cured by gold based complexes. Clinically approved drugs such as aurothio glucose and disodium aurothiomalate are designed based on the fact that gold (I) is the most stable state in vivo. Patients suffering from severe anemia caused by iron deficiency are administered intravenously with dextran (Proferdex, Dexferrum, InFeD) or iron sucrose (Venofer) to replace the missing iron (II) ion. The potential of Vanadium supplementation in maintaining blood glucose levels in diabetics is well-accepted. Particularly, the vanadium (IV) complex, bis(maltolato)oxovanadium(IV), exhibits marked insulin enhancing and anti-diabetic effects [2].

\section{Metals as diagnostic agents}

Complexes of radioactive metal ions and paramagnetic metal ions are now widely used as contrasting agents in Magnetic Resonance Imaging (MRI) for the diagnosis of disease. Remarkable improvement in the quality of the MRI data is obtained when a contrast agent is employed. Some gadolinium (III) complexes and manganese (II) salts are useful for imaging brain tumors and heart, respectively. Ferric (III) chloride improves gastrointestinal tract images in humans. Such complex is delivered to the patient intravenously and is carried round in the blood plasma but does not enter the cells. Among the radio nuclides commonly employed in organ and tissue imaging purpose in nuclear medicine, technetium-99m ( $99 \mathrm{mTc})$ is the most effective one [3].

\section{Anticancer agents}

The approval of cis-diamminedichloroplatinum (cisplatin) by Food and Drug Administration (FDA) in 1978 as a chemotherapeutic agent has encouraged researchers to explore efficient complexes with anti-cancer properties. Cisplatin is a square planar platinum complex with the metal in the +2 oxidation state. The cytotoxicity of cisplatin originates 
from its binding to DNA which causes significant distortion of helical structure and results in inhibition of DNA replication and transcription [4]. Cisplatin is used for the treatment of testicular cancer, ovarian cancer, and lung cancer as well as for cervical, head and neck cancers. However, clinical use of cisplatin against malignancies is severely limited by doselimiting side-effects such as neuro-, hepati- and nephrotoxicity. This leads to the subsequently discovery of other platinum based drugs like carboplatin and oxaliplatin, in which the side-effects of cisplatin are considerably reduced by the chelate effect of the ligand. Some octahedral ruthenium (III) and ruthenium(II) complexes are found to display anti tumour activity especially against metastatic cancers and this are also promising candidates as cancer drugs [5].

\section{Conclusion}

In $21^{\text {st }}$ century, a great percentage of global population is affected by various fatal diseases and metallodrugs hold tremendous potential to help mankind with the discovery of modern medicines related to cancer care, infection control, diabetic control, neurological and cardiovascular disorders. With the understanding of the fate of the coordination complex and its components in the biological environment, it will be possible to design new systems endowed with improved responsiveness and targeting capabilities.

\section{References}

1. Silva JJRFD, Williams RJP (1991) The Biological Chemistry of the Elements. Clarendon Press: Oxford, UK 20(1): 62-63.

2. Kraatz HB, Metzler-Nolte N (2006) Concepts and Models in Bioinorganic Chemistry. Wiley-VCH: Weinheim, Germany.

3. Thompson KH, Orvig C (2003) Science 300: 936.

4. Jones CJ, Thornback JR (2007) Medicinal Applications of Coordination Chemistry. Royal Society of Chemistry: Cambridge, UK.

5. Sigel A, Sigel H (2007) Metal Ions in Biological Systems \& Metal Ions in Life Sciences, various books and numerous chapters.

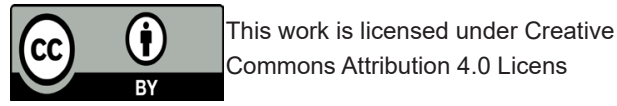

\section{Your next submission with Juniper Publishers} will reach you the below assets

- Quality Editorial service

- Swift Peer Review

- Reprints availability

- E-prints Service

- Manuscript Podcast for convenient understanding

- Global attainment for your research

- Manuscript accessibility in different formats ( Pdf, E-pub, Full Text, Audio)

- Unceasing customer service

Track the below URL for one-step submission https://juniperpublishers.com/online-submission.php 